\title{
Effects of osmotic priming using aerated solutions of polyethylene glycol on germination of pine seeds*
}

\author{
S.W. Hallgren \\ Department of Forestry, Oklahoma State University, Stillwater, OK 74078, USA
}

(received 15-2-1988; accepted 7-6-1988)

\begin{abstract}
Summary - Osmotic priming with aerated solutions of polyethylene glycol improved both final germination and rapidity of germination in loblolly and shortleaf pines, and was generally detrimental to germination of slash pine seeds. Priming solutions with water potentials of -0.8 and $-1.0 \mathrm{MPa}$ were most effective and the beneficial effects were greatest for germination at low temperature. Stratification prior to treatment eliminated the beneficial effect of priming on total germination but not on rapidity of germination. The aerated solution method of priming could be upgraded to handle large quantities of seed.
\end{abstract}

seed - germination — Pinus taeda - osmotic priming

Résumé - Effets d'un prétraitement osmotique dans des solutions aérées de polyéthylène glycol sur la germination des graines de pins. Des graines de Pinus taeda $L$. (loblolly pine), $P$. elliottii Engelm. (slash pine) et de P. echinata Mill. (shortleaf pine) ont reçu des prétraitements osmotiques dans des solutions aérées de polyéthylène glycol (PEG). Elles ont ensuite été mises à germer afin d'étudier les effets du prétraitement sur la vitesse et le taux de germination. On a de plus comparé, pour les graines de loblolly pine et de slash pine, l'effet de la présence ou de l'absence d'une stratification au froid préalable au prétraitement osmotique. En revanche, les graines de shortleaf pine ont toutes été stratifiées. Les essais de germination ont été réalisés à deux températures : 1) en dessous de l'optimum, à $15^{\circ} \mathrm{C}$; 2) à température voisine de l'optimum, à $25^{\circ} \mathrm{C}$. En général, les prétraitements osmotiques ont surtout amélioré la vitesse de germination et, en l'absence de stratification, le taux de germination de loblolly et shortleaf pine, mais les effets ont été négatifs pour le slash pine (Tableaux Ià III). Les solutions de PEG à $-0,8$ et -1 MPa ont donné les meilleurs résultats. Les effets du prétraitement ont été plus importants pour les graines placées à une température inférieure à l'optimum que pour celles qui étaient placées en température optimale (Tableaux l et II). La stratification avant le prétraitement a éliminé l'effet du prétraitement osmotique sur le taux mais pas sur la vitesse de germination. Ce système de prétraitement osmotique dans des solutions aérées pourrait être modifié pour de grandes quantités de graines.

graines - germination - Pinus taeda - prétraitement osmotique

*Oklahoma Agricultural Experiment Station Journal Article No. 5363. 


\section{Introduction}

Osmotic priming has been tested extensively with seeds of annual crops and has shown promise as a technique for improving seed vigor (Heydecker et al., 1973; Heydecker and Coolbear, 1977). This technique has been tested only occasionally with three seeds (Muller and BonnetMasimbert, 1983; Haridi, 1985). First suggested many years ago (Levitt and Hamm, 1943), osmotic priming has been used to improve germination under stressful conditions (O'Sullivan and Bouw, 1984; Valdes et al., 1985). Seeds are imbibed in an osmoticum that allows all the processes of germination to proceed to completion except radical emergence. Following the treatment the seeds are rinsed and redried. When they are sown, primed seeds germinate more rapidly and uniformly than untreated seeds (Bradford, 1986).

Recently, an improved seed priming system was developed at Oklahoma State University that provides greater flexibility to adjust the priming conditions and the possibility of upgrading to handle large quantities of seeds (Akers et al., 1984; Akers and Holley, 1986). This paper reports the results of several tests of this system with loblolly pine (Pinus taeda L.), slash pine ( $P$. elliottii Engelm.) and shortleaf pine ( $P$. echinata Mill.).

\section{Materials and Methods}

The seeds used in this study included two bulk lots of improved loblolly pine seed harvested in 1980 (LLP1) and 1985 (LLP2) and two of slash pine seed harvested in 1981 (SLP1) and 1985 (SLP2). The seeds were supplied by the Texas Forest Service. The shortleaf pine seeds came from a bulk lot of 12 open-pollinated families harvested at various times over the previous 7 years and supplied by the Oklahoma Division of Forestry.

Both stratified and unstratified loblolly and slash pine seeds were given one of several priming treatments or no priming. Stratification was carried out by imbibing seeds for $24 \mathrm{~h}$ in water at room temperature $\left(25^{\circ} \mathrm{C}\right)$, draining the seeds and then stratifying them with no medium in polyethylene bags at $1-3^{\circ} \mathrm{C}$ for 53 days prior to priming.

The seeds were primed in transparent columns of vigorously aerated priming solutions at $25^{\circ} \mathrm{C}$. The priming solutions were prepared from polyethylene glycol (PEG), molecular weight 8000 , and water so that the resulting water potentials were $-0.8,-1.0,-1.2$ and -1.4 $\mathrm{MPa}$. Each column contained $300 \mathrm{ml}$ of solution and 400 seeds. Both the priming treatments and subsequent germination tests were conducted under natural light.

Loblolly and slash pine seeds were primed for 11 days. Solutions were replaced with new solutions on days 1, 2, 3, 5, 7 and 9 . At the end of the treatment period none of the slash pine seeds had germinated, and a maximum of $6.5 \%$ of the loblolly pine seeds had germinated in one of the solutions at $-0.8 \mathrm{MPa}$. The groups of seeds that were stratified and not primed remained in stratification during the priming and thus received a total of 64 days of stratification. Immediately following priming the seeds were placed in 2 germinators, one at constant $25^{\circ} \mathrm{C}$ and another at $15^{\circ} \mathrm{C}$. At $25^{\circ} \mathrm{C}$ the temperature is near optimum for germination of southern pines and $15^{\circ} \mathrm{C}$ is considered stressful (Dunlap and Barnett, 1984). In each germinator the treatments were arranged in 4 replicates of 50 seeds, each on moist filter paper in a randomized complete block design.

In a separate experiment, shortleaf pine seeds were stratified for 36 days and then primed in PEG solutions at $0.0,-0.8,-1.0,-1.2$ and $-1.4 \mathrm{MPa}$. Solutions were changed daily. After 5 days of priming most of the seeds at 0.0 $\mathrm{MPa}$ and many at $-0.8 \mathrm{MPa}$ had germinated; these seeds were discarded and the treatments were terminated. A germination test was run at $25^{\circ} \mathrm{C}$ for primed seeds and unprimed seeds that remained in stratification during priming and received a total of 41 days of stratification. After 59 days of stratification another group of shortleaf pine seeds from the same lot were primed in a solution at 1.0 MPa for 5 days. A germination test was carried out at $15^{\circ} \mathrm{C}$ to compare these primed seeds with unprimed seeds strati- 
fied for 64 days. The germination tests for shortleaf pine were conducted in a refrigerator at the specified temperature under artificial light and $a 16 \mathrm{~h}$ photoperiod.

In the tests germination was counted every day at first, and less frequently as germination slowed until germination appeared to be complete. Germination was complete after 37 days for loblolly and slash pines and after 20-22 days for shortleaf pine. Analysis of variance and the least significant difference were used to determine the significance of treatment effects on final percent germination and the median germination day (number of days to reach $50 \%$ of the final total germination (Steel and Torrie, 1980).

\section{Results}

\section{Loblolly Pine}

In general, LLP2 showed a slightly higher percent germination and a more rapid germination than LLP1 and both seed lots showed nearly the same response to priming (Table I). At $25^{\circ} \mathrm{C}$ the effect of priming on percent germination of unstratified seeds ranged from no change to a $26 \%$ increase. Priming of stratified seeds showed no effect on percent germination for LLP2 and a slightly negative effect for

Table I. Effects of priming on germination at $25^{\circ} \mathrm{C}$ of stratified and unstratified loblolly and slash pine seeds (1).

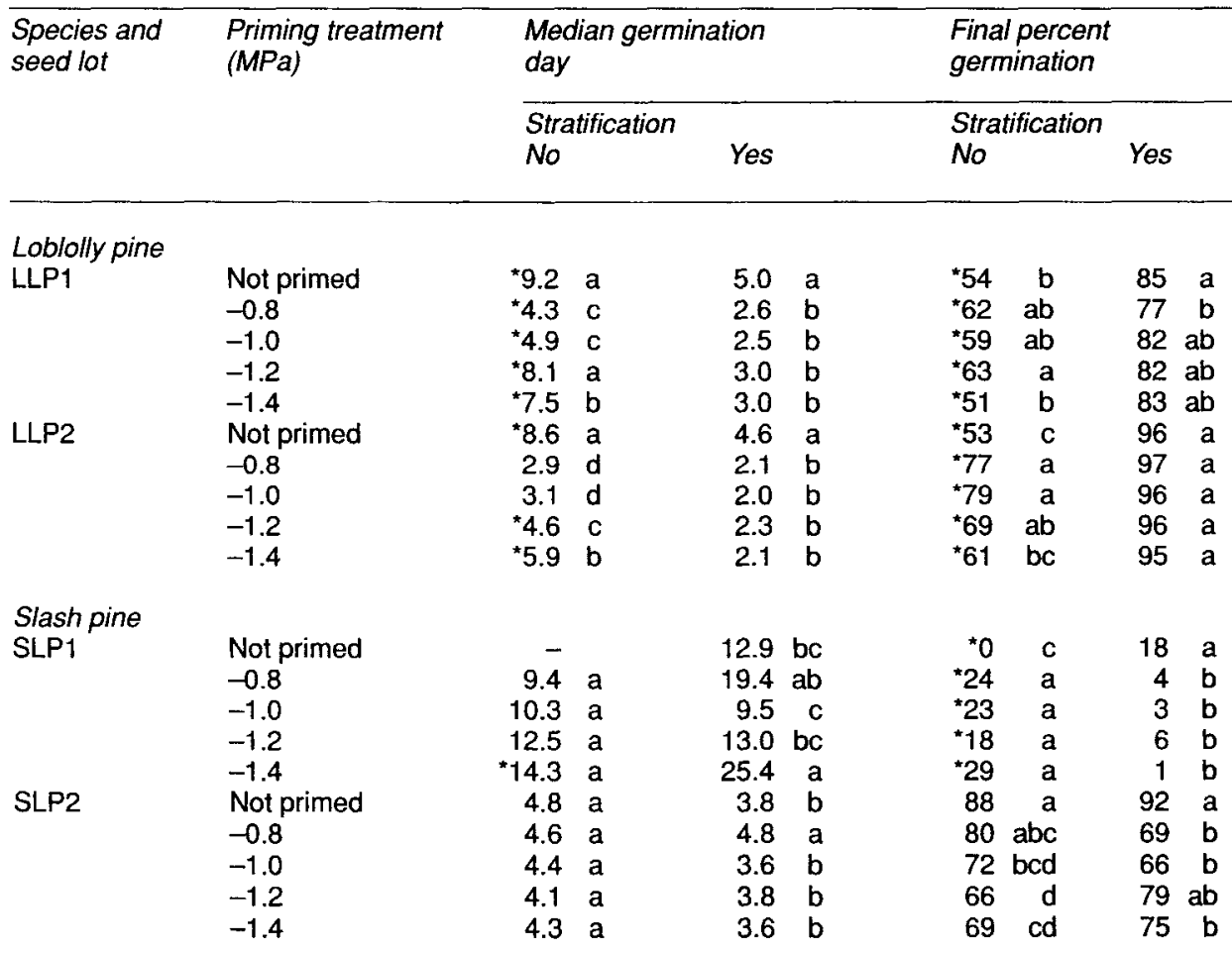

(1) For each seed lot and stratification treatment, means followed by the same letter are not different at the 5 percent level and for each level of priming, the asterisk indicates the effect of stratification was significant at the 5 percent level. 
Table II. Effects of priming on germination at $15^{\circ} \mathrm{C}$ of stratified and unstratified loblolly and slash pine seeds (1).

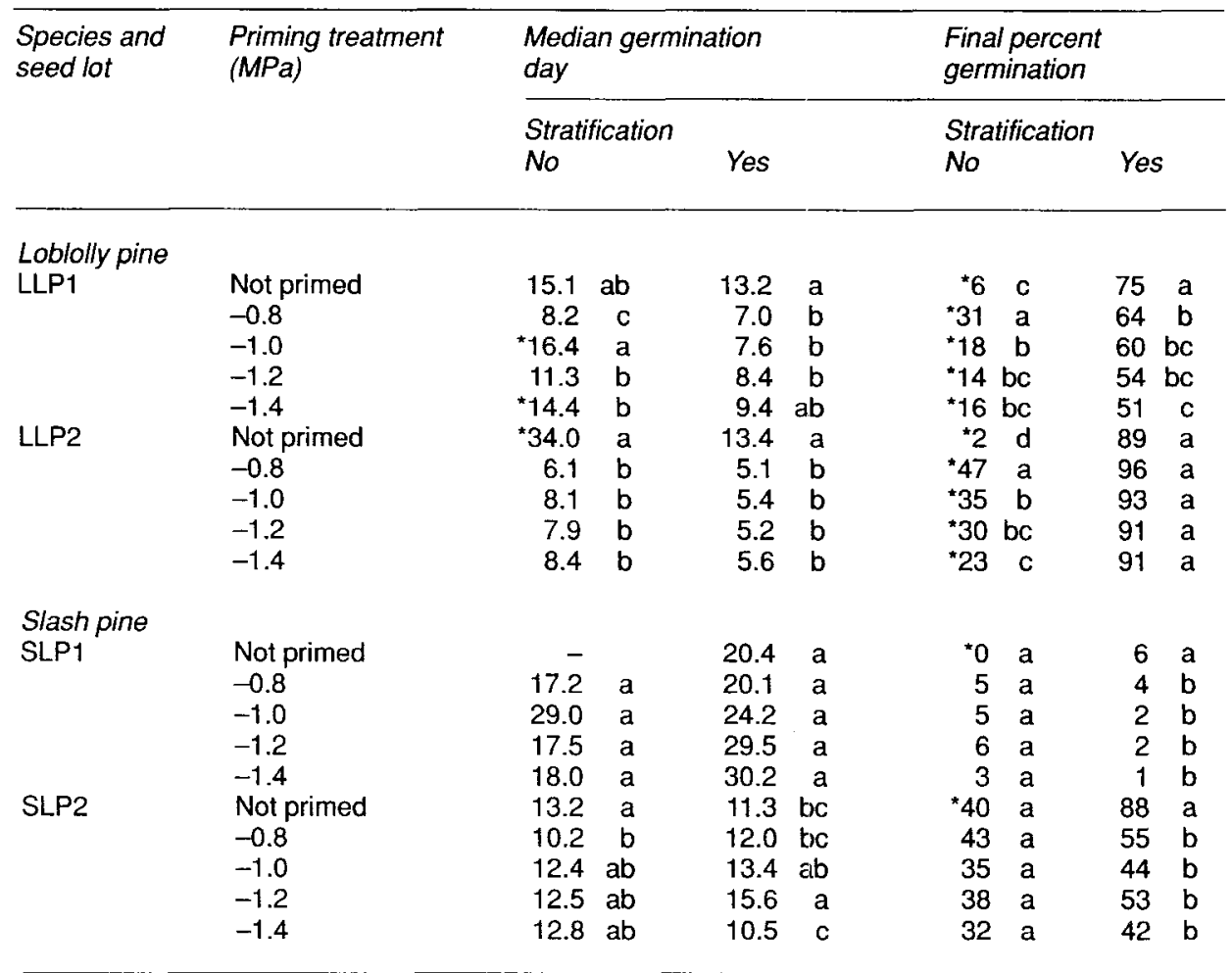

(1) For each seed lot and stratification treatment, means followed by the same letter are not different at the 5 percent level and for each level of priming, the asterisk indicates the effect of stratification was significant at the 5 percent level.

LLP1. The median germination day was reduced up to half by priming for both stratified and unstratified seeds.

At a germination temperature of $15^{\circ} \mathrm{C}$, priming greatly increased percent germination of unstratified seeds (Table II). The percent germination of stratified seeds showed no effect of priming for LLP2 and a decrease for LLP1. Low percent germination for unstratified seeds made it difficult to interpret the effect of priming on rapidity of germination. Priming reduced the median germination day for stratified seeds by 40 and 60 percent. In general, priming solutions of -0.8 and $-1.0 \mathrm{MPa}$ showed the best results at both $15^{\circ} \mathrm{C}$ and $25^{\circ} \mathrm{C}$.

\section{Slash Pine}

In general, SLP1 showed much lower percent germination and much slower germination than SLP2. Priming showed a negative effect on percent germination and no effect on rapidity of germination for both stratified and unstratified seeds germinated at $25^{\circ} \mathrm{C}$ and $15^{\circ} \mathrm{C}$ (Tables $I$ and II). One exception was unstratified seeds of SLP1 germinated at $25^{\circ} \mathrm{C}$, which showed an increase from $0 \%$ germination with no priming to up to $29 \%$ with priming. 
Table III. Effects of priming on germination at $15^{\circ} \mathrm{C}$ and $25^{\circ} \mathrm{C}$ of stratified shortleaf pine seeds (1).

\begin{tabular}{llll}
\hline $\begin{array}{l}\text { Germination } \\
\text { temperature }\end{array}$ & $\begin{array}{l}\text { Priming } \\
\text { treatment }(\mathrm{MPa})\end{array}$ & $\begin{array}{l}\text { Median germination } \\
\text { day }\end{array}$ & $\begin{array}{l}\text { Final percent } \\
\text { germination }\end{array}$ \\
\hline $25^{\circ} \mathrm{C}$ & Not primed & $3.7 \mathrm{a}$ & $98 \mathrm{a}$ \\
& -0.8 & - & - \\
& -1.0 & $1.0 \mathrm{~b}$ & $93 \mathrm{ab}$ \\
& -1.2 & $0.8 \mathrm{~b}$ & $85 \mathrm{~b}$ \\
$15^{\circ} \mathrm{C}$ & -1.4 & $0.8 \mathrm{~b}$ & $81 \mathrm{~b}$ \\
& Not primed & $9.2 \mathrm{a}$ & $94 \mathrm{a}$ \\
& -0.8 & - & - \\
& -1.0 & $2.5 \mathrm{~b}$ & $97 \mathrm{a}$ \\
& -1.2 & - & - \\
\hline
\end{tabular}

(i) For each germination temperature, means followed by the same letter are not different at the 5 percent level.

\section{Shortleaf Pine}

At $25^{\circ} \mathrm{C}$ percent germination of stratified seed was unaffected by priming at -1.0 $\mathrm{MPa}$ and decreased by $13-17 \%$ at lower water potentials (Table III). Priming reduced the median germination day by 70 $80 \%$. The priming treatment showing the best overall results was $-1.0 \mathrm{MPa}$.

When seeds were germinated at $15^{\circ} \mathrm{C}$, priming at $-1.0 \mathrm{MPa}$ did not affect percent germination of stratified seed but reduced the median germination day by $73 \%$ (Table III).

\section{Discussion and Conclusions}

The results of this study demonstrated that osmotic priming can increase the rapidity of germination of loblolly and shortleaf pine seeds. Also, priming can increase final germination of unstratified loblolly pine and in some cases slash pine seeds (Tables 1-II). A large number of studies with crop species have shown generally positive results from priming (Bradford, 1986). This study has shown that there is a potential for using priming to improve the vigor of tree seeds.
In the current study stratification increased final germination and rapidity of germination of loblolly pine seeds (Tables I and II). However, stratified seeds showed a reduced priming effect on rapidity of germination and no effect or a negative effect of priming on final germination. Apparently when dormancy is removed by stratification, priming is less effective. Nonetheless, the combination of priming and stratification usually produced the most rapid and highest percent germination for loblolly pine.

Slash pine seeds appeared to be less dormant than loblolly pine seeds, as stratification did not affect rapidity of germination (Tables I and II). Also, one seed lot showed only modest increases in percent germination due to stratification and the other only showed an increase at $15^{\circ} \mathrm{C}$. Although priming improved the percent germination for one lot of unstratified slash pine seed, when the seeds were stratified priming consistently reduced percent germination for both lots. Perhaps the priming treatment used in the current study was not the optimum for slash pine.

Maximum improvement in germination was attained from priming at water potentials of -0.8 to $-1.0 \mathrm{MPa}$. At lower water 
potentials the effect was smaller, apparently due to less water uptake and the concomitant reduction in seed metabolism. A longer period of priming may have increased the beneficial effects of priming at lower water potentials.

In a previous study, osmotic priming improved germination of slash pine (Haridi, 1985) while in the current study the results were inconsistent for the 2 lots. Furthermore, loblolly and slash pine and stratified and unstratified seeds responded differently to priming. It is apparent that results from priming can be expected to vary among species, seed lots and conditions of the seeds.

The current study showed that priming can stimulate germination at suboptimal temperatures (Tables II and III). Low temperature has been suggested to be a potential cause of sluggish germination of loblolly pine in forest nurseries (Dunlap and Barnett, 1984). Osmotic priming may be a practical method of overcoming the adverse effect of low temperature.

Rapid uniform germination and early growth are important, since plants at the early developmental stages are especially susceptible to damage by environmental stresses, insects and diseases. The current study showed that priming can stimulate germination in loblolly and shortleaf pine in the laboratory; the next step is to determine whether priming can improve germination and seedling performance in the nursery. The practical application of priming may be in treating seed lots when time constraints do not permit the longer stratification treatment which may be 60-90 days for some lots of loblolly pine (McLemore and Czabator, 1961; McLemore, 1969). Also, priming of stratified seeds may be warranted when especially rapid germination is desired under adverse conditions such as cold weather.

\section{Acknowledgınents}

This research was done as part of the Oklahoma State University's Agricultural Experiment Station Project No. OKLO1979. The author wishes to thank S.W. Akers, J.P. Barnett and F.T. Bonner for their helpful comments on the manuscript and S.W. Akers for help in adapting the priming technique to pine seeds.

\section{References}

Akers S.W., Holley K.E. \& Ager P. (1984) A screening process to establish effective priming treatments for vegetable seed. Hortscience 19, 211

Akers S.W. \& Holley K.E. (1986) SPS : a system for priming seed using aerated polyethylene glycol or salt solutions. Hortscience 21, 529-531

Bradford K.J. (1986) Manipulation of seed water relations via osmotic priming to improve germination under stress conditions. Hortscience 21, 1105-1112

Dunlap J.R. \& Barnett J.P. (1984) Manipulating loblolly pine (Pinus taeda L.) seed germination with simulated moisture and temperature stress. In : Seedling Physiology and Reforestation Success (M.L. Duryea \& G.N. Brown, eds.), Martinus Nijhoff/Dr. W. Junk Publ., Boston, pp. $61-74$

Haridi M.B. (1985) Effect of osmotic priming with polyethylene glycol on germination of Pinus elliottii seeds. Seed Sci. Technol. 13, 669-674

Heydecker W., Higgins J. \& Gulliver R.L. (1973) Accelerated germination by osmotic seed treatment. Nature 246, 42-44

Heydecker W. \& Coolbear P. (1977) Seed treatment and improved performance - survey and attempted prognosis. Seed Sci.Technol. 5, 353424

Levitt J. \& Hamm P.C. (1943) A method of increasing the rate of seed germination of Taraxacum Kok-Saghyz. Plant Physiol. 18, 288293 
McLemore B.F. \& Czabator F.J. (1961) Length of stratification and germination of loblolly pine seed. J. For. 59, 267-269

McLemore B.F. (1969) Long stratification hastens germination of loblolly pine seed at low temperatures. J. For. 67, 419-420

Muller C. \& Bonnet-Masimbert M. (1983) Amélioration de la germination des faînes (Fagus silvatica) par prétraitement en présence de polyéthylène glycol. Ann. Sci. For. 40, 157-164
O'Sullivan J. \& Bouw W.J. (1984) Pepper seed treatment for low-temperature germination. Can. J. Plant Sci. 64, 387-393

Steel R.G.D. \& Torrie J.H. (1980) Principles and Procedures of Statistics. McGraw-Hill, New York, 2nd edn, pp. 633

Valdes V.M., Bradford K.J. \& Mayberry K.S. (1985) Alleviation of thermodormancy in coated lettuce seeds by seed priming. Hortscience 20 , $1112-1114$ 